\title{
Performance of Broilers Reared under Monochromatic Light Emitting Diode Supplemental Lighting
}

http://dx.doi.org/10.1590/1516-635x1704553-558

-Author(s)

\section{Guevara BDM'}

Pech PS'

Zamora BR

Navarrete SLFI

Magaña SHF'

Instituto Tecnológico de Conkal

\section{Mail Address}

Corresponding author e-mail address HF Magaña Sevilla

Instituto Tecnológico de Conkal, Avenida Tecnológico, Conkal, México.

Phone: 52999124130

Fax: 52999124131

Email: hectorms68@hotmail.com

\section{"Keywords}

Light Emitting Diode, Light intensity photoperiod, light wavelength, broiler.
Submitted: September/2014

Approved: April/2015

\section{ABSTRACT}

The purpose of this study was to evaluate the effect of green monochromatic light emitting diodes (LED) or white fluorescent lamps on the growth performance of broilers reared in open houses. Two hundred broilers (Ross 308) were sexed and divided into four treatments, according to sex and supplemental light source: T1, males under green LED; T2, males under fluorescent lamps; T3, females under green LED; and $\mathrm{T} 4$, females under fluorescent lamps, totaling 50 birds per treatment with five replicates each $(n=10)$. Broilers of both sexes received natural light during the day and supplemental lighting (fluorescent or LED) during the night, according to age. Individual body weight, mortality, and feed intake were recorded weekly per replicate. Feed conversion ratio and the European Efficiency Index (EEI) were calculated. Data were analyzed by a two-way ANOVA. The results indicated differences $(p<$ $0.05)$ in female body weight in week $6,(2202.31 \pm 32.93 \mathrm{~g}$ green LED vs $2191.08 \pm 62.13 \mathrm{~g}$ fluorescent lamp), but no differences in daily weight gain, feed conversion ratio, or mortality were detected. However, the use of green LED promoted higher EEI in males in weeks 5, 6, and 7, and in females in week $5(p<0.05)$. Green monochromatic LED may be used for supplemental lighting of male broilers reared in open houses with natural light. Its use for female broilers is recommended if the birds are marketed up to 5 weeks of age.

\section{INTRODUCTION}

Broiler production systems of broilers present different management and facility characteristics, leading the producers to apply alternatives to increase production efficiency. Among the features that enable sustainability of animal production systems, the highest productivity per area is essential, making of environmental control a key component of farm profitability. Artificial lighting programs have a proven influence on weight gain and feed conversion ratio (Abreu et al., 2011), because they can be used as an exogenous element for the control of physiological and behavioral processes. Their manipulation modulates circadian rhythms, body temperature, and feed intake and digestion in poultry. Lighting is necessary for the bird's vision, influencing visual acuity and color discrimination (Calvet et al., 2009). Light color modifies the patterns of secretion of hormones related to growth, maturation, and reproduction (Olanrewaju et al., 2006).

The lighting process consumes a significant part of the electrical energy used on the farm. Fossil fuels used for electric power generation are becoming more difficult and expensive to obtain, and produce $\mathrm{CO}_{2}$ emissions to the troposphere (Peñuelas and Carnicer, 2010). Additionally, Mexico's government regulation established that incandescent bulbs are would not allowed to be sold after December 
2013. After that date, only fluorescent lamps, more efficient than incandescent bulbs, will be available, but are the only source of the use of mercury that will grow in the years to come, because fluorescent bulbs contain Hgdust and vapor, harmful to both humans and the environment when inappropriately disposed (Pawlowski, 2011). Compared with other light sources, the Light Emitting Diodes (LED) have long life (50,000 hours) and low power consumption, there are evidences that they may improve broiler productivity (Karakaya et al., 2009). Broilers reared under green LED showed better performance and muscle growth (Rozemboim et al., 2013). However, the information on the use of LED as a source of supplemental lighting in broiler houses with natural illumination is limited, even when open houses or negative-pressure ventilated houses with clear curtains are used because the consumer's preference for pigmented meat, or when mobile curtains are used in open-sided houses for temperature control.

The objective of this study was to evaluate the effect of monochromatic green LED light on the performance and production efficiency of broilers reared in open houses.

\section{MATERIALS AND METHODS}

The experiment was conducted in Yucatán, México, at $20^{\circ} 58$ ' $04^{\prime \prime}$ north latitude and $89^{\circ} 37^{\prime} 18^{\prime \prime}$ west longitude.

Two hundred on-day-old Ross 308 broilers were sexed (100 males and 100 females) and vaccinated against Marek's disease at hatch. Birds were housed in an open-sided broilers house receiving natural lighting during the day, and equipped with fans, 500 watt infrared lamps, plastic feeders and automatic drinkers. A two-phase feeding program was applied in order to minimize management variation. The starter feed (121 days) contained $22 \%$ crude protein (CP) and 3,100 kcal of metabolizable energy (ME), and the finisher feed (22-49 days) contained 18\% CP and 3,200 kcal of ME. Feed was offered ad libitum. Feeder and drinker height and position were established by the Ross 308 Broiler Management Handbook (2014).

\section{Lighting treatments}

The $3 \times 9 m$ facility with a $3 m$ height was divided with a geomembrane, allowing the allocation of the two lighting treatments in a $12 \mathrm{~m}^{2}$ area each. The number and position of LED and fluorescent lamps were determined by adjustments in lamp height, number, and distribution. A light intensity of 45 lux at the level of chick, was achieved with two 4 watts/h monochromatic green LED at $50 \mathrm{~cm}$ height, and one white fluorescent bulb of 12 watts/h at $1.6 \mathrm{~m}$ height. Light homogeneous distribution and intensity at the bird's level, and luminous isolation of the treatments were verified with a Digital Light Meter (HER-410, Range 0 50000 Lux, Steren, México).

The chicks were exposed during the first four days of age to a lighting program of $23 \mathrm{~h}$ of light and one $\mathrm{h}$ of dark. Subsequently, the lighting schedule duration decreased 0:30 min of light per day until $18 \mathrm{~h}$ of light and $6 \mathrm{~h}$ of darkness was achieved. The supplemental lighting program started at sunset, and ended at sunrise.

Birds were distributed according to a completely randomized design into four different groups (two groups of males and two of females). The house was divided into 20 pens of $1.5 \times 1.8 \mathrm{~m}$ with 2.54 $\mathrm{cm}$ hexagonal poultry netting. Discounting the feeder (37 cm diameter) and drinker areas, pen density of 11 birds $/ \mathrm{m}^{2}$ (Fig. 1). The treatments were consisted of sex and source of supplemental light: T1, males with green LED; T2 males with fluorescent lamps; T3, females with green light LED; T4, females with fluorescent lamps, with 50 birds per treatment and five replicates (pens) of 10 each.

Each individual chick was weighed at placement (day zero), on day 4, and weekly thereafter to determine body weight. Feed intake was measured by weighing the food offered and rejected on weekly basis. Daily weight gain was calculated as body weight (g) at the determined age minus body weight on day zero, divided between days of age. Feed conversion ratio (FCR) was calculated as weekly feed intake divided by body weight per pen. Mortality was recorded daily and weekly. The European Efficiency Index (EEI) was calculated as [livability (\%) $\times$ body weight $(\mathrm{kg}) /$ age (days) $\times F C R] \times 100$.

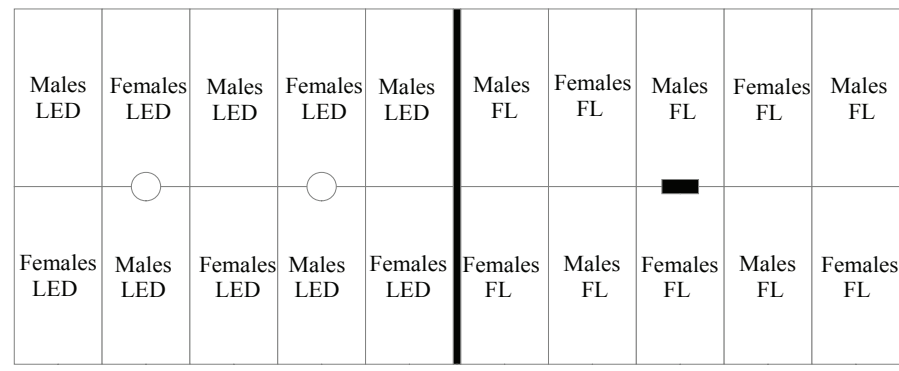

Figure 1 - Top View of experimental poultry house, indicating LED, (Green LED treatments); FL, (Fluorescent lamp treatments), circles indicates LED placement, and the black rectangle the Fluorescent lamp. (Not to scale) 
Data were submitted to two-way analysis of variance and means were compared by the test of Bonferroni, with an experimental error of $p<0.05$, using GraphPad Prism version 5.00 for Windows statistical software.

\section{RESULTS}

Male and female body weights were similar (Table $1)$, except in week 6, when females under fluorescent light were significantly lighter $(p<0.05)$ than those submitted to the other treatments. In general, body weights were slightly lower than those indicated by the standards of the commercial line.

No body weight differences ( $p>0.05$ ) were detected between males and females under LED. However, it cannot be ascertained that this effect was due to poor male performance or good female performance.

Lighting programs must be designed to allow sufficient time for broilers to perform vital functions required for adequate growth. In the commonly practiced lighting schemes, with alternating periods of light and darkness, a primordial principle is to provide the birds with light intervals that allows them to ingest enough feed during the hours of light and to allow feed flow from the crop during the dark period. Therefore, it was expected that the LED light would promote heavier weights, as reported by Rozemboim (2013) and Cao et al. (2013), who showed higher weight gain and better feed conversion ratio in broilers when monochromatic green, blue or their combinations was applied compared with white lamps.

Daily weight gain may explain the lack of differences in body weight between treatments (Table 2), as no statistical differences were found among treatments. Males presented poorer performance compared to the genetic line standard, and was not influenced light source.

No feed conversion ratio differences were detected among treatments (Table 3). Due to the growth dynamics of broilers after week 5, females were expected to present worse FCR than males, but this trend was not observed in the present study, and both males and females had worse FCR than the standards of their genetic line. When LED was used as light source, the average FCR was 2.29 in week 5, which were lower that the FCR of 3.0 obtained by Cao et al. (2008) using white LED light; however, the latter evaluated FCR in week 7.

Table 1 - Mean body weight (g) of broilers reared under green light emitting diodes (LED) or white fluorescent bulbs as supplemental light source.

\begin{tabular}{|c|c|c|c|c|c|c|c|}
\hline \multirow[t]{2}{*}{$\begin{array}{l}\text { Age } \\
\text { Weeks }\end{array}$} & \multicolumn{2}{|c|}{$\begin{array}{l}\text { Males } \\
\text { LED }\end{array}$} & \multicolumn{2}{|c|}{$\begin{array}{c}\text { Males } \\
\text { Fluorescent }\end{array}$} & \multicolumn{2}{|c|}{$\begin{array}{c}\text { Females } \\
\text { LED }\end{array}$} & \multirow{2}{*}{$\begin{array}{c}\text { Females } \\
\text { Fluorescent } \\
\text { Mean }\end{array}$} \\
\hline & Mean & S.E & Mean & S.E & Mean & S.E & \\
\hline 1 & 156.18 & \pm 1.96 & 156.68 & \pm 0.98 & 146.24 & \pm 2.97 & 149.98 \\
\hline 2 & 385.39 & \pm 60.9 & 383.80 & \pm 5.95 & 375.95 & \pm 7.42 & 368.21 \\
\hline 3 & 751.10 & \pm 4.28 & 768.97 & \pm 8.44 & 748.37 & \pm 10.30 & 755.71 \\
\hline 4 & 1154.60 & \pm 9.62 & 1205.20 & \pm 7.96 & 1139.35 & \pm 19.57 & 1154.70 \\
\hline 5 & 1702.60 & \pm 28.12 & 1729.22 & \pm 10.75 & 1654.75 & \pm 21.94 & 1666.72 \\
\hline 6 & $2262.49^{c b}$ & \pm 27.67 & $2288.93^{b}$ & \pm 26.53 & $2202.31^{b}$ & \pm 32.93 & $2191.08^{a}$ \\
\hline 7 & 2601.87 & \pm 27.25 & 2642.67 & \pm 38.34 & 2579.59 & \pm 22.97 & 2565.32 \\
\hline
\end{tabular}

$a, b, c$ means in the same row not sharing a common superscript statistically differ $(p<0.05)$.

Table 2 - Average daily weight gain (g) of broilers reared under green light emitting diodes (LED) or white fluorescent lamps as supplemental light source.

\begin{tabular}{|c|c|c|c|c|c|c|c|}
\hline \multirow[t]{2}{*}{$\begin{array}{l}\text { Age } \\
\text { Weeks }\end{array}$} & \multicolumn{2}{|c|}{$\begin{array}{l}\text { Males } \\
\text { LED }\end{array}$} & \multicolumn{2}{|c|}{$\begin{array}{c}\text { Males } \\
\text { Fluorescent }\end{array}$} & \multicolumn{2}{|c|}{$\begin{array}{c}\text { Females } \\
\text { LED }\end{array}$} & \multirow{2}{*}{$\begin{array}{c}\begin{array}{c}\text { Females } \\
\text { Fluorescent }\end{array} \\
\text { Mean }\end{array}$} \\
\hline & Mean & S.E & Mean & S.E & Mean & S.E & \\
\hline 1 & 22.31 & \pm 0.280 & 22.38 & \pm 0.140 & 20.890 & \pm 0.420 & 21.43 \\
\hline 2 & 27.53 & \pm 0.440 & 27.41 & \pm 0.420 & 26.850 & \pm 0.530 & 26.3 \\
\hline 3 & 35.77 & \pm 0.200 & 36.62 & \pm 0.400 & 35.640 & \pm 0.490 & 35.99 \\
\hline 4 & 41.24 & \pm 0.340 & 43.04 & \pm 0.280 & 40.690 & \pm 0.700 & 41.24 \\
\hline 5 & 48.64 & \pm 0.800 & 49.41 & \pm 0.310 & 47.280 & \pm 0.630 & 47.62 \\
\hline 6 & 53.87 & \pm 0.660 & 54.5 & \pm 0.630 & 52.440 & \pm 0.780 & 52.17 \\
\hline 7 & 53.1 & \pm 0.560 & 53.93 & \pm 0.780 & 52.640 & \pm 0.470 & 52.35 \\
\hline
\end{tabular}


Table 3 - Feed conversion ratio $(\mathrm{kg} / \mathrm{kg}$ ) of broilers reared under green light emitting diodes (LED) or white fluorescent bulbs as supplemental light source.

\begin{tabular}{|c|c|c|c|c|c|c|c|}
\hline \multirow[t]{2}{*}{$\begin{array}{l}\text { Age } \\
\text { Weeks }\end{array}$} & \multicolumn{2}{|c|}{$\begin{array}{l}\text { Males } \\
\text { LED }\end{array}$} & \multicolumn{2}{|c|}{$\begin{array}{c}\text { Males } \\
\text { Fluorescent }\end{array}$} & \multicolumn{2}{|c|}{$\begin{array}{c}\text { Females } \\
\text { LED }\end{array}$} & \multirow{2}{*}{$\begin{array}{c}\text { Females } \\
\text { Fluorescent } \\
\text { Mean }\end{array}$} \\
\hline & Mean & S.E & Mean & S.E & Mean & S.E & \\
\hline 1 & 1.6 & \pm 0.020 & 1.63 & \pm 0.037 & 1.78 & \pm 0.044 & 1.7 \\
\hline 2 & 1.67 & \pm 0.048 & 1.71 & \pm 0.048 & 1.64 & \pm 0.049 & 1.23 \\
\hline 3 & 2.11 & \pm 0.092 & 2.18 & \pm 0.065 & 2.35 & \pm 0.040 & 1.98 \\
\hline 4 & 2.13 & \pm 0.096 & 2.1 & \pm 0.061 & 2.92 & \pm 0.022 & 2.12 \\
\hline 5 & 2.09 & \pm 0.103 & 2.05 & \pm 0.059 & 2.19 & \pm 0.033 & 1.91 \\
\hline 6 & 2.37 & \pm 0.106 & 2.26 & \pm 0.116 & 2.38 & \pm 0.066 & 2.1 \\
\hline 7 & 2.64 & \pm 0.111 & 2.59 & \pm 0.123 & 2.62 & \pm 0.062 & 2.42 \\
\hline
\end{tabular}

There were no differences $(p<0.05)$ in cumulative mortality (Table 4)

However, the low mortality rates recorded during the experiment indicates that overall management conditions were satisfactory for animal growth. Another important parameter in broiler production that aids evaluating management conditions is flock weight uniformity. In this case, the coefficients of variation of weekly body weight were not statistically different among treatments, and were consistent with the recommended average for the broiler strain used (Table 5).

Until here, individual performance parameters per treatment were analyzed. The European Efficiency
Index (EEI) consolidates performance parameters into a general index, which allows comparing productivity among flocks in an integrated and objective approach. Although no statistical differences were found in performance parameters in general, the calculated EEI was statistically different among treatments $(p<0.05$; Table 6).

Male reared under green LED showed the best performance. The differences between males and females under LED or florescent treatments are due to inherent better performance of male broilers. The exception were the males reared under fluorescent lights on week 7, which EEI was not different from the females under LED or fluorescent light. Females under

Table 4 - Cumulative mortality of broilers reared under green light emitting diodes (LED) or white fluorescent bulbs as supplemental light source.

\begin{tabular}{lccccccc}
\hline $\begin{array}{l}\text { Age } \\
\text { Weeks }\end{array}$ & $\begin{array}{c}\text { Males } \\
\text { LED }\end{array}$ & Mean & \multicolumn{2}{c}{$\begin{array}{c}\text { Males } \\
\text { Fluorescent }\end{array}$} & & $\begin{array}{c}\text { Females } \\
\text { LED }\end{array}$ & $\begin{array}{c}\text { Females } \\
\text { Fluorescent }\end{array}$ \\
\hline & Mean & S.E & S.E & Mean & S.E & Mean \\
\cline { 2 - 7 } 1 & 0 & \pm 0 & 0.4 & \pm 0.4 & 0.8 & \pm 0.49 & 0.4 \\
2 & 0 & \pm 0 & 0.8 & \pm 0.49 & 0.8 & \pm 0.49 & 0.8 \\
3 & 0 & \pm 0 & 1.2 & \pm 0.8 & 1.2 & \pm 0.49 & 1.2 \\
4 & 0 & \pm 0 & 1.2 & \pm 0.8 & 1.2 & \pm 0.49 & 1.2 \\
5 & 0 & \pm 0 & 1.2 & \pm 0.8 & 1.2 & \pm 0.49 & 1.2 \\
6 & 0.4 & \pm 0.4 & 1.6 & \pm 0.75 & 1.6 & \pm 0.75 & 2 \\
7 & 0.8 & \pm 0.49 & 2 & \pm 0.63 & 1.6 & \pm 0.75 & 2 \\
\hline
\end{tabular}

Table 5 - Coefficients of variation of weekly body weight of broilers reared under green light emitting diodes (LED) or white fluorescent bulbs as supplemental light source.

\begin{tabular}{|c|c|c|c|c|c|c|c|}
\hline \multirow[t]{2}{*}{$\begin{array}{l}\text { Age } \\
\text { Weeks }\end{array}$} & \multicolumn{2}{|c|}{$\begin{array}{l}\text { Males } \\
\text { LED }\end{array}$} & \multicolumn{2}{|c|}{$\begin{array}{c}\text { Males } \\
\text { Fluorescent }\end{array}$} & \multicolumn{2}{|c|}{$\begin{array}{c}\text { Females } \\
\text { LED }\end{array}$} & \multirow{2}{*}{$\begin{array}{c}\text { Females } \\
\text { Fluorescent } \\
\text { Mean }\end{array}$} \\
\hline & Mean & S.E & Mean & S.E & Mean & S.E & \\
\hline 1 & 7.25 & \pm 0.54 & 8.11 & \pm 0.59 & 12.96 & \pm 4.91 & 9.53 \\
\hline 2 & 8.90 & \pm 0.88 & 10.06 & \pm 1.64 & 10.69 & \pm 2.10 & 11.71 \\
\hline 3 & 10.34 & \pm 0.703 & 8.41 & \pm 1.02 & 9.49 & \pm 0.87 & 8.73 \\
\hline 4 & 8.93 & \pm 1.03 & 8.82 & \pm 0.97 & 7.72 & \pm 1.21 & 9.10 \\
\hline 5 & 9.80 & \pm 1.17 & 9.92 & \pm 0.70 & 8.86 & \pm 1.29 & 9.66 \\
\hline 6 & 10.99 & \pm 1.33 & 10.73 & \pm 0.46 & 7.52 & \pm 1.14 & 11.33 \\
\hline 7 & 11.94 & \pm 0.88 & 11.78 & \pm 0.53 & 10.14 & \pm 1.26 & 10.52 \\
\hline
\end{tabular}


Table 6 - European Efficiency Index (EEI) of broilers reared under green light emitting diodes (LED) or white fluorescent bulbs as supplemental light source.

\begin{tabular}{|c|c|c|c|c|c|c|c|}
\hline \multirow[t]{2}{*}{$\begin{array}{l}\text { Age } \\
\text { Weeks }\end{array}$} & \multicolumn{2}{|c|}{$\begin{array}{l}\text { Males } \\
\text { LED }\end{array}$} & \multicolumn{2}{|c|}{$\begin{array}{c}\text { Males } \\
\text { Fluorescent }\end{array}$} & \multicolumn{2}{|c|}{$\begin{array}{c}\text { Females } \\
\text { LED }\end{array}$} & \multirow{2}{*}{$\begin{array}{c}\begin{array}{c}\text { Females } \\
\text { Fluorescent }\end{array} \\
\text { Mean }\end{array}$} \\
\hline & Mean & S.E & Mean & S.E & Mean & S.E & \\
\hline 5 & $254.83^{c}$ & \pm 4.21 & $226.46^{b}$ & \pm 1.41 & $202.29^{a}$ & \pm 2.68 & $215.5^{b}$ \\
\hline 6 & $251.64^{c}$ & \pm 3.08 & $222.88^{b}$ & \pm 2.58 & $202.80^{\mathrm{a}}$ & \pm 3.03 & $198.30^{a}$ \\
\hline 7 & $210.25^{b}$ & \pm 2.20 & $187.68^{a}$ & \pm 2.72 & $184.69^{a}$ & \pm 1.64 & $179.06^{a}$ \\
\hline
\end{tabular}

$a, b, c$ means in the same row not sharing a common superscript differ $(p<0.05)$

LED presented the same EEI in weeks 6 and 7, but fluorescent lighting promoted higher EEI in week 5 . These findings indicate that supplemental light source must be chosen according to the final product desired.

\section{DISCUSSION}

There is evidence that light wavelength influences broiler performance, and our results are consistent with those of Rozemboin et al. (1999), who established that broilers respond differently to different light colors. Evaluating the effects of white (incandescent), blue, red, or green light on broiler performance, Rozemboin et al. (1999) obtained higher growth rates and heavier body weights in broilers reared under green and blue light, as well as higher testosterone plasma levels in blue light environments, and more development of breast muscles under green light. Based on these findings, Rozemboin et al. (2004) worked with blue and green lights and switching from one to another color, and their results suggest that green light stimulates broiler growth at an early age, and changing the birds to a different light environment at 10 or 20 days of age stimulated growth. The findings of the present study are consistent with the results of Mendes (2010), who found colored lights promoted better broiler performance than white light. The relevant difference between Rozemboim's studies and the present experiment is that artificial lighting was used as supplemental lighting, because broilers were under natural (solar) light during the day, and artificial light only in the afternoon and night. Other researchers also obtained better broiler performance with colored lights. Karakaya et al. (2009), for instance, found significantly higher feed intake, body weight and total muscle weight in broilers reared under green light or combined blue and green light compared with those reared under white incandescent light. This suggests that green light may be required for broiler growth. In study of Karakaya et al.(2009), only female broilers were used and performance in response to light is expected to be different between males and females, as found in the present study. Santana et al. (2014) did not find any broiler performance differences when LED or fluorescent light were used. The main difference in the present study was detected when EEI was evaluated, as it allows comparing overall parameters.

Animal behavior and welfare may be affected by light color, according to Kristensen et al. (2007), who described that broilers preferred warm-white fluorescent light sources than incandescent light, regardless the intensity of light. Broilers also showed an "elastic time-budget". Resting behavior (61\% of their time) of broilers was not affected by light wavelength, but there was less feather pecking behavior under white light and less foraging behavior in darker than in brighter light intensities.

\section{CONCLUSIONS}

Light wavelength affects broiler performance, including of those reared in open houses with natural (solar) lighting, which are frequent in tropical climates. Monochromatic green LED is an alternative to incandescent light bulbs, promoting similar performance as that obtained with fluorescent lights. In addition, LED reduces production costs, due to energy savings and their long lifetime. In the present study, the evaluation of the EEl showed differences in broiler responses to the type of light source, depending on sex and age, and therefore, when choosing light sources for broilers houses, the final product should be taken into consideration.

\section{REFERENCES}

Abreu V, Abreu P, Coldebella A, Jaenisch F, dos Santos J, de Paiva, D. Curtain color and lighting program in broiler production: I - general performance. Revista Brasileira de Zootecnia 2011;40(9):2026-2034.

Allen HP. Electric utilities: can they meet future power needs? The Annals of the American Academy of Political and Social Science 1973;410:86-96.

Calvet S, Van den Weghe H, Kosch R, Estellés F. The Influence of the lighting program on broiler activity and dust production. Poultry Science 2009;88:2504-2511. 
Cao J, Liu W, Wang Z, Xie D, Jia L, Chen Y. Green and blue monochromatic lights promote growth and development of broilers via stimulating testosterone secretion and growth myofiber. Journal of Applied Poultry Research 2008;17:211-218.

Karakaya M, Parlat SS, Yilmaz MT, Yildirim I, Ozalp B. Growth performance and quality properties of meat from broiler chickens reared under different monochromatic light sources. British Poultry Science 2009;50:76-82.

Kristensen HH, Prescott NB, Perry GC, Ladewig J, Ersbøll AK, Overvad KC, et al. The behaviour of broiler chickens in different light sources and illuminances. Applied Animal Behaviour Science 2007;103:75-89.

Mendes AS, Paixão SJ, Restelatto R, Morello GM, Jorge de Moura D, Possenti JC. Performance and preference of broiler chickens exposed to different lighting sources. Journal of Applied Poultry Research 2013;22(1):62-70

Olanrewaju HA, Thaxton JP, Dozier WA, Purswell J, Roush WB, Branton $\mathrm{SL}$. A review of lighting programs for broiler production. International Journal of Poultry Science 2006;5:301-308.

Pawlowski L. Effect of mercury and lead on the total environment. Environment Protection Engineering 2011;1:105-117.

Peñuelas J, Carnicer J. Climate change and peak oil: the urgent need for a transition to a non-carbon-emitting society. Ambio 2010;39(1):85-90.
Petek M, Sönmez G, Yildiz H, Baspinar H. Effects of different management factors on broiler performance and incidence of tibial dyschondroplasia. British Poultry Science 2005;46:16-21.

Ross. Broiler management handbook [cited 2014 Oct 5]. 2014. Available from: http://es.aviagen.com/assets/Tech_Center/Ross_Broiler/RossBroiler-Handbook-2014-EN.pdf

Rozenboim I, Biran I, Chaiseha Y, Yahav S, Rosenstrauch A, Sklan D, et al. The effect of a combination of green and blue monochromatic light on broiler growth and development. Poultry Science 2004;83:842-845.

Rozenboim I, Biran I, Uni Z, Robinzon B, Halevy O. The effect of monochromatic light on broiler growth and development. Poultry Science 1999;78:135-138

Rozenboim I, El Halawani ME, Kashash Y, Piestun Y, Halevy O. The effect of monochromatic photostimulation on growth and development of broiler birds. General and Comparative Endocrinology 2013;190:214219

Santana MR, Garcia RG, Naas IA, Paz IC, Caldara FR, Barreto B. Light emitting diode (LED) use in artificial lighting for broiler chicken production. Engenharia Agrícola 2014;34(3):422-427.

Sorensen P, Su G, Kestin SC. Effects of age and stocking density on leg weakness in broiler chickens. Poultry Science 2000;79:864-870. 